\title{
Analysis of Current Ratio Changes Effect, Asset Ratio Debt, Total Asset Turnover, Return On Asset, And Price Earning Ratio In Predictinggrowth Income By Considering Corporate Size In The Company Joined In Lq45 Index Year 2013 -2016
}

\author{
Wikan Budi Utami \\ STIE-AAS Surakarta \\ Email: wikan.budiutami@yahoo.com
}

\begin{abstract}
This study aims to determine the effect of the partially and simultaneously of the Current Ratio (CR), Debt Asset Ratio (DAR), Total Asset Turnover (TATO), Return On Assets (ROA), and Price Earning Ratio (PER) in predicting profit growth by considering firm size at company incorporated in LQ45 index year 2013 -2016 with company size as control a variable. The technique of determining the sample in this research is by using purposive sampling. There are several criteria that must be met by companies listed in the LQ45 Index to be sampled in this study. This research method is using multiple regression analysis which is used to know the influence of independent variable to the dependent variable together and partially. The t test is used to test the influence of each variable change Current Ratio, Debt Asset Ratio, Total Asset Turnover, Return On Asset, and Price Earning Ratio to earnings growth variable with firm size as control variable. The statistical test $F$ aims to examine the effect of changes in Current Ratio, Debt Asset Ratio, Total Asset Turnover, Return On Asset, and Price Earning Ratio simultaneously to the variable of profit growth with firm size as control variable. The R2 test (Coefficient of determination) is done to find out how big the influence variable change Current Ratio, Debt Asset Ratio, Total Asset Turnover, Return On Asset, and Price Earning Ratio to variable growth profit with company size as control variable. From result of $t$ test is known that change of Total Assets Turn Over and change of Return On Assets partially have significant effect to profit growth $(\triangle E A T)$. Variable change of Curent Ratio ( $\triangle C R$ ), change of Debt Asset Ratio ( $\triangle D A R)$, Price Earning Ratio ( $\triangle P E R$ ) partially no significant effect on profit growth variable with firm size as control variable. From result of $F$ test, it is known that Current Ratio ( $\triangle C R$ ) change, Debt Asset Ratio (A

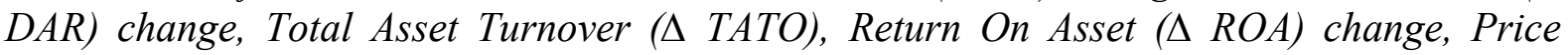
Earning Ratio ( $\triangle$ PER) simultant significant effect on profit growth variable at go public company listed in index LQ 45 in Indonesia with company size) as control variable.
\end{abstract}

Keywords: change of CR, DAR, TATO, ROA, PER, profit growth.

\section{Introduction}

The rapid development of capital markets has made investors excited again in investing in companies that offer high profits. One of the lure of investors in investing in companies is the profit offered by the company. Companies that provide high returns to investors will be reflected in good corporate financial performance. Good earnings changes, suggesting that the company has a good financial performance, which in turn will increase the value of the company (Simorangkir, 1993). Profit growth is a change in the percentage increase in profit earned by the company.

The main purpose of financial ratio analysis is to give an indication of company performance in the future. Financial ratios are used to predict corporate earnings. An increase or decrease in profit will affect the other ratios of Curent Ratio (liquidity ratio), Debt Assets Ratio (solvency ratio), activity ratio (Total Assets Turn Over) and profitability ratio (Return On Assets). According to Riyanto (1995) in general, 
financial ratios can be grouped into liquidity ratio, solvency ratio (leverage), activity ratio and profitability ratio. The four ratios will be very useful for the management in carrying out its operations or activities of the company, especially in planning and decision making short term and long term.

In addition to profit that becomes another consideration for investors in investing capital is by looking at the value of a company. A company value can be reflected from financial information, corporate financial flows and financial performance of the company.

Some research on the ability of financial ratios in predicting earnings has been done with many diverse results, namely:

Dra. Isnaniah Laili Khatmi Safitri, MMA (2016) conducted a study to determine the influence of various financial ratios to profit growth of PT. Kalbe Farma tbk. Variable Inventory turnover has a significant influence on profit growth of PT. Kalbe Farma tbk, Variable Return on equity has no significant effect to profit growth of PT. Kalbe Farma tbk. Simultaneously debt to asset ratio, net profit margin, inventory turnover and return on equity have a significant effect on profit growth.

I Nyoman Kusuma Adnyana Mahaputra investigated the effect of current ratio, debt to equity ratio, total assets turnover, and profit margin on profit growth. The test results show that the current ratio, debt to equity, total asset turnover, and profit margin have a significant influence on profit growth.

Based on the findings of the researchers described above, the authors are interested in re-testing the ability of the liquidity ratio (Cureent Ratio), solvency (Debt Assets Ratio), activity (Total Assets Turn Over), profitability (Return On Assets), and market ratio (Total Assets Turn OverRatio) in predicting profit growth by considering the size effect.

\section{Literature Review}

\subsection{Theoretical Review}

\section{a. Financial Ratio Analysis}

Financial ratio analysis is an analytical tool that gives an indication that the company has sufficient cash to fulfill its financial obligations, the amount of receivables is quite rational, the efficiency of the company's inventory management, the planning of good investment and healthy Return On Assets so that the goal of maximizing shareholder wealth can be achieved (Agus Sartono, 2001). The ratios typically used are as follows:

a. Liquidity Ratio

According to Toto Prihadi (2008) liquidity is the company's ability to pay off shortterm liabilities. Liquidity measurements typically associate short-term liabilities with current assets available to pay them off. Although this ratio does not speak of solvency issues, but a bad liquidity ratio in the long run will also affect the solvency of the company. The measure of corporate liquidity in this research is Current Ratio (CR). Current Ratio (CR) is obtained by comparing current assets and current liabilities. The higher the current assets (relative to current debt) the higher the current ratio, which also means the higher the level of corporate liquidity. But, the higher the amount of unused cash that will ultimately lower the level of profitability. Thus, there is always a trade-off between liquidity and profitability (Handono Mardiyanto, 2008).

$$
\text { Current ratio }=\frac{\text { current Assets }}{\text { Current Liabilitie S }}
$$

b. Solvency Ratio

This ratio measures the company's ability to meet its long-term liabilities. A non solvable company is a company whose total debt is greater than its total assets. This ratio measures the company's long-term liquidity and thus focuses on the right side of the balance sheet. Solvency ratios used in this research are: Debt To Total Assets Ratio. Debt To Total Assets This ratio calculates how far funds are provided by creditors. 
The high ratio of total debt to total assets indicates that the company uses high financial leverage (financial leverage). Use of high financial leverage will increase the stock capital equity (Return On Equity) quickly. However, on the contrary, if sales decrease in capital stocks equity will decrease.

Debt To Tatal Assets Ratio $=\frac{\text { Total Liabilities }}{\text { Total Assets }}$

\section{Activity Ratio}

This ratio looks at several assets and then determines what level of activity these assets have at a given level of activity. Low assets at a certain level of sales will result in an increasing amount of excess funds embedded in these assets. Excess funds will be better invested in other assets that are more productive. Activity ratio used is Total Asset Turn Over (TATO).

Total Asset Turn Over (TATO) is an overall measure of asset turnover. This ratio is quite often used because of its overall coverage. Regardless of the type of business, this ratio can illustrate how well the support of all assets to obtain sales (Toto Prihadi, 2008).

\section{Profitability Ratio}

$$
\text { Total Asset Turn Over }=\frac{\text { Sales }}{\text { TotalAssets }}
$$

The profit margin ratio shows the company's ability to generate net income at certain sales levels. This ratio can be seen directly in the common-size analysis for the income statement. A low profit margin signifies a company's ability to generate profits that are too low for a certain level of cost, or a cost too high for a certain level of sales, or a combination of both. In general, a low ratio may indicate inefficient management. The ratios used in calculating profitability are Return On Investment (ROI), Return On Equity (ROE) and Return On Assets (ROA).

Return On Investment (ROI) measures the ability of a company with overall funds invested in assets used for the company's operations in generating profits.

$$
R O I=\frac{\text { Earning } \text { After } \text { Taxes }}{\text { SaleTotal Assetss }}
$$

While Return On Equity (ROE), measure the ability of companies to generate profits based on certain capital stock.

$$
\text { ROE }=\frac{\text { Net } \text { Profit }}{\text { Total Equety }}
$$

Return on Assets (ROA) is the profitability ratio to measure the company's ability to generate profits by using the total existing assets and after the capital costs (the costs used to fund the assets) are excluded from the analysis. ROA is the ratio of tax net profit which also means a measure to assess how much the return of assets owned by the company. (Bambang Riyanto, 1997).

$$
R O A=\frac{\text { Net Operating Income }}{\text { Total Assets }} \times 100 \%
$$

\section{Market Ratios}

The company's high Price Earning Ratio (PER) reflects good growth and has good prospects. But in terms of investors, the price Earning Ratio (PER) that is too high may not be attractive because stock prices will probably not rise again which means the possibility of gaining capital gains will be smaller.

$$
\begin{aligned}
& \text { Price Earning Ratio (PER) } \\
& =\frac{\text { harga pasar per lembar saham }}{\text { laba bersih per lembar saham }}
\end{aligned}
$$

\section{b. Company Profit}

Net income becomes the result of operations after the interest and tax period. Profit change is a factor that can be used for project activities, as this is because the quantity or volume of goods sold has a direct relationship to the sales activities. In addition, growth can also be generated by components - components of liquidity, profitability, solvency and activity.

\section{c. Company Size (Size Effect)}

Company size (Size effect) is one tool to measure the size of a company. Employees, 
assets, sales, market value and value added are some common measures to determine the size of a company (Hart and Oulton in Juliana, 2003). There are some fundamental differences between large companies and small companies. Elton and Gruber in Juliana (2003) say larger-sized companies will have easier access to the capital market than small companies. Small-company share of the trading frequency level is not as fast and as easy as a large company's stock. Scherer in Juliana (2003) found evidence that larger companies are more stable and growth patterns can change rapidly than small firms. This may be because the ability of large companies to make various product lines and operations easier. Damayanti in Juliana (2003) in his research consider the size of the company seen from the total assets. The results obtained are firm assets have no effect on the ability to predict financial ratios to future earnings growth in manufacturing companies.

\subsection{Previous Study}

Several previous studies that have been conducted include:

Dra. Isnaniah Laili Khatmi Safitri, MMA (2016) conducted a study to determine the influence of various financial ratios to profit growth of PT. Kalbe Farma tbk. The result of this research is Debt to Asset Ratio variable has significant influence to profit growth of PT. Kalbe Farma tbk, Variable Current Ratiotidak significant effect on profit growth of PT. Kalbe Farma tbk. Variable Inventory turnover has a significant influence on profit growth of PT. Kalbe Farma tbk, Variable Return on equity has no significant effect to profit growth of PT. Kalbe Farma tbk. Simultaneously debt to asset ratio, net profit margin, inventory turnover and return on equity have a significant effect on profit growth.

Nita Hari Susanti (2014) conducted research with the aim to analyze and test ratio of Total Assets Turnover, Net Profit Margin, and Return on Assets in predicting future earnings growth in automotive companies in Indonesia Stock Exchange. This study shows (1) Total Assets Turnover, Net Profit Margin, and Return on Assets simultaneously have a significant effect on profit growth; (2) Total Assets Turnover, Net Profit Margin, and Return on Assets partially significant effect to profit growth; (3) Return on Assets have dominant influence to earnings growth because have coefficient value of partial determinasi.

Ade Gunawan and Sri Fitri Wahyunu (2013) conducted research with the aim to: (1) partially test the influence of financial ratios on profit growth in trading companies in Indonesia Stock Exchange. (2) simultaneously test the influence of financial ratios on profit growth in trading companies in Indonesia Stock Exchange (3) to know the most dominant financial ratios affecting profit growth in trading companies in Indonesia Stock Exchange (4) to know aspect of asset and income management and aspect debt and equity to profit growth in trading companies in Indonesia Stock Exchange.

R. Adisetiawan tested the effect of Working Capital to Total Asset (WCTA), Current Liabilities To Inventory (CLI), Operating Income to Total Assets (OITL), Total Asset Turnover (TAT), Current Ratio (NPM) and Gross Profit Margin ) to earnings growth. From result of regression analysis show that variable of Operating Income to Total Assets (OITL) and Current Ratio (NPM) partially have significant effect to profit growth. While the variable Working Capital to Total Asset (WCTA), Current Liabilities To Inventory (CLI), Total Asset Turnover (TAT), and Gross Profit Margin (GPM) have no significant effect on profit growth. The six variables used in this study (WCTA, CLI, OITL, TAT, NPM and GPM) simultaneously have no significant effect on profit growth, with predictive ability of the six variables of $4.4 \%$.

I Nyoman Kusuma Adnyana Mahaputra investigated the effect of current ratio, debt to equity ratio, total assets turnover, and 
profit margin on profit growth. The test results show that the current ratio, debt to equity, total asset turnover, and profit margin have a significant influence on profit growth.

\subsection{Hypothesis}

a. Curret Ratio changes partially significant effect on the profit growth of companies incorporated in the LQ45 Index $2013-2016$ with the size of the company as a control variable.

b. Changes in Debt Assets Ratio partially significant effect on the profit growth of companies incorporated in the LQ45 Index 2013 -2016 with the size of the company as a control variable.

c. Changes Total Assets Turnover partially significant effect on the profit growth of companies incorporated in the LQ45 Index 2013 -2016 with the size of the company as a control variable.

d. Changes in Return On Assets partially significant effect on the profit growth of companies incorporated in the LQ45 Index 2013 -2016 with the size of the company as a control variable.

e. Changes in Price Earning Ratio partially significant effect on the profit growth of companies incorporated in the LQ45 Index 2013 -2016 with the size of the company as a control variable.

f. Curret Ratio Changes, Debt Assets Ratio, Total Assets Turnover, Return On Assets and Price Earning Ratio changes simultaneously have a significant effect on the profit growth of companies incorporated in the LQ45 Index of $2013-2016$ with firm size as control variables

\subsection{Theoretical Framework}

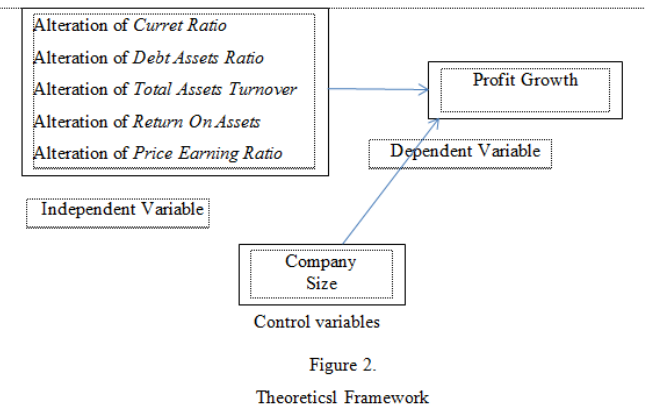

\section{Research Methodology}

This research is descriptive quantitative, which explains the relationship between variables by analyzing numerical data (numbers) using statistical methods through hypothesis testing. This research is a case study research company incorporated in the index LQ45 in Indonesia Stock Exchange in 2013-2016.

\subsection{Data Source, Population, Sample, Data Collection Method}

The data required from this study consists of Annual Reports published by the company that became the object of research.

The population used for this research is all companies incorporated in LQ45 period 2013-2016 yag listed on Indonesia Stock Exchange (BEI).

The technique of determining the sample in this research is by using purposive sampling. Criteria of companies incorporated in the LQ45 period 2013-2016 listed on the Indonesia Stock Exchange (IDX) to be able to sample in this study are:

a. Companies incorporated in LQ45 period 2013-2016.

b. Companies that are not engaged in services.

c. Issue financial statements as of December 31, 2013 - 2016.

d. Having financial statement data related to the measurement of variables in the study.

e. During the study period companies have a positive profit.

\subsection{Research Variables and Operational Definition of Variables}

a. Dependent variable in this research is relative profit growth. Profit growth used is profit after tax. With the calculation as follows: 


$$
\Delta Y_{i t}=\frac{\left(Y_{i t}-Y_{i t-1}\right)}{Y_{i t-1}}
$$

b. Independent variables in this study are changes in liquidity, solvency, activity activity, profitability, and Ratio Pasar.Yang calculated by the formula:

$$
\Delta F_{r i t}=\frac{F_{r i t}-F_{r i t-1}}{F_{r i t-1}}
$$

Whereas:

1) $\Delta$ Frit $=$ Changes in Current Ratio (CR), Debt Assets Ratio (DAR), Total Asset Turn Over (TATO), Return On Assets (ROA), Price Earning Ratio (PER).

2) Fit = Current Ratio (CR), Debt Assets Ratio (DAR), Total Asset Turn Over (TATO), Return On Assets (ROA), Price Earning Ratio (PER).

3) Frit $-1=$ Current Ratio (CR), Debt Assets Ratio (DAR), Total Asset Turn Over (TATO), Return On Assets (ROA), Price Earning Ratio (PER) for $\mathrm{t}$ period for $\mathrm{t}-1$ period.

c. Control variables

The control variable serves to see if with the inclusion of a number of control variables into the model, the main independent variable significantly becomes stronger. In this study the size effect is used as a control variable. Company size is measured by the average total assets. The total assets of the manufacturing company being sampled is averaged over the analysis period, then averaged by all manufacturing firms with arithmatic mean.

$$
\mathrm{X}=\frac{x_{1}+x_{2}+x_{3}+\ldots \ldots . .+x_{n}}{n}=\frac{\sum_{x}}{n}
$$

Whereas:

$\mathrm{X}=$ average total assets of all manufacturing companies. $\mathrm{x}_{1}, \mathrm{x}_{2}, \ldots \ldots \mathrm{xn}=$ the average total assets of each company during the analysis period.

$\mathrm{N}=$ total number of manufacturing companies.

The size of the company is categorized into two levels ie large companies and small companies. Companies whose total assets are above the average of all manufacturing firms are categorized as large companies and whose total assets are below average all manufacturing firms are categorized as small firms. Company size is a dummy variable, valued at 0 if the firm is small and is worth 1 if it is a large company.

\subsection{Data Analysis Techniques}

\subsubsection{Data Quality Test Normality test}

Normality test aims to test whether in the regression model, the dependent variable and the independent variable, both have a normal distribution or not. A good regression model is to have normal or nearnormal data distribution. In this study, the normality test of data used statistical test Kolmograv Smirnov with the criteria used is to compare the value of significance has been determined that is equal to $5 \%(0.05)$. If the probability value obtained is greater than 0.05 then the data is normally distributed.

\section{Autocorrelation Test}

The test done to detect this autocorrelation is Durbin Watson test. ie by comparing the value of Durbin Watson count (d) with its critical value or table value. If the value (d) lies between the upper bound (du) and (4$\mathrm{du})$, the autocorrelation coefficient is zero, meaning there is no autocorrelation.

\section{Multicollinearity Test}

This test is to test whether there is a linear relationship between independent variables in the regression model and to indicate whether there is a high degree of cholinearity among the independent variables. Multicolinearity test is done by 
looking at tolerance value and variance inflation factor (VIF). Commonly used values are tolerance values above 0.10 or with VIF values less than 10 .

\section{Heteroscedasticity Test}

Aimed to test whether there is a variance inequality of the residual of a observation to another observation in the regression model. To detect the occurrence of heteroskedastisitas in this study then used Spearman Rank Method by way of regretting the independent variables with residual variables which then correlated matrices. If the residual probability value is greater than $\alpha=0.05$; then there is no symptoms of heteroskedastisitas vice versa if the value of residual is smaller than $\alpha=$ 0.05 ; then there will be symptoms of heteroscedasticity.

\section{Hypothesis Test}

a. Multiple Regression

Multiple regression analysis is used to determine the effect of independent variables (CR, DAR, TATO, ROA, PER) and control variables (SIZE) on dependent variable (Growth of profit) together and partially. In this research the multiple regression equation is:

$\mathrm{Y}=\mathrm{a}+\mathrm{b}_{1} \mathrm{X}_{1}+\mathrm{b}_{2} \mathrm{X}_{2}+\mathrm{b}_{3} \mathrm{X}_{3}+\mathrm{b}_{4} \mathrm{X}_{4}+\mathrm{b}_{5} \mathrm{X}_{5}+$ $\mathrm{b}_{6} \mathrm{X}_{6++} \mathrm{e}$ (Anto Dayan, 2000)

Whereas:

\begin{tabular}{|c|c|c|}
\hline & & $\begin{array}{l}\text { Unstandardize } \\
\text { d Residual }\end{array}$ \\
\hline \multicolumn{2}{|l|}{$\mathrm{N}$} & 56 \\
\hline \multirow{2}{*}{$\begin{array}{l}\text { Normal } \\
\text { Parameters }{ }^{\mathrm{a}, \mathrm{b}}\end{array}$} & Mean & .0000000 \\
\hline & Std. Deviation & .18304339 \\
\hline \multirow{3}{*}{$\begin{array}{l}\text { Most Extreme } \\
\text { Differences }\end{array}$} & Absolute & .155 \\
\hline & Positive & .155 \\
\hline & Negative & -.124 \\
\hline \multicolumn{2}{|c|}{ Kolmogorov-Smirnov Z } & 1.158 \\
\hline \multicolumn{2}{|c|}{ Asymp. Sig. (2-tailed) } & .137 \\
\hline
\end{tabular}

$\mathrm{Y}=$ Variable Growth Earning After Taxes $\mathrm{X}_{1}=$ Variable Growth Current Ratio (CR) $\mathrm{X}_{2}=$ Variable Growth Debt Assets Ratio (DAR)

$\mathrm{X}_{3}=$ Growth Variable Total Asset Turn Over (TATO) $\mathrm{X}_{4}=$ Growth Variable Return On Assets
(ROA)

$\mathrm{X}_{5}=$ Variable Growth Price Earning Rati (PER)

$\mathrm{X}_{6}=$ Variable Growth Control of Company Size

a: constants

b: regression coefficient

e: error term

b. $t$ Test

This $t$ test is used to test the influence of each independent variable (CR, DAR, TATO, ROA, PER) to variable growth of profit with firm size as control variable.

c. F Test

The statistical $F$ test aims to examine the effect of all independent or independent variables (CR, DAR, TATO, ROA, PER) and control variables (SIZE) together on the dependent or dependent variable (profit growth).

d. Coefficient of determination $\left(\mathrm{R}^{2}\right)$

This test is conducted to find out how much the influence of independent variables $(\mathrm{CR}$, DAR, TATO, ROA, PER) and control variables (SIZE) to the dependent variable (profit growth).

\section{Finding and Discussion}

\subsection{Data Analysis \\ 4.1.1 Classic Assumption Test}

a. Normality test

Normality test was performed by Kolmogorov Smirnov test from the residual value of a regression model (Ghozali, 2005). Good data is normally distributed data. From the test results of Kolmogorof Smirnov normality that appears in table 4.1 above shows the significance value of 1.158 $>\alpha=0.005$ then the data is normally distributed.

\section{b. Autocorrelation Test}

Table 4.2

Test Results of Auto Correlation Durbin-Watson Method 
Peer Reviewed - International Journal

Vol-1, Issue-1, 2017 (IJEBAR)

ISSN: 2614-1280, https://jurnal.stie-aas.ac.id/index.php/IJEBAR

\begin{tabular}{|c|c|c|c|}
\hline Variabel & D-W & Kriteria & Kesimpulan \\
\hline $\mathrm{X} 1, \mathrm{X} 2$, & 1,914 & $4-\mathrm{du}>\mathrm{DW}>$ & There is no \\
$\mathrm{X} 3, \mathrm{X} 4, \mathrm{X} 5$ & & $\mathrm{du}$ & problem \\
& & $2,2322>1,914$ & \\
& & $>1,7678$ & \\
& & & \\
\hline
\end{tabular}

Data source: secondary data processed, 2017

The term autocorrelation can be defined as the correlation between members of a series of observations sorted (Gujarati, 1991: 2001). A good regression model is a regression independent of autocorrelation. To determine whether there is autocorrelation symptoms in the regression calculation of this study, it will be used durbin watsen test (DW TES). From the results of the above table it is known that the $\mathrm{D}-\mathrm{W}$ test value of 1.914 where the number is between du $=1.7678$ and $4-d u=$ 2,2322 it can be concluded there is no autocorrelation, then the model used in this study is feasible for basic analysis.

c. Heteroscedasticity test with Glejser test The purpose of the heteroscedasticity test is to test whether in the regression model there is a variance inequality of the residual one observation to the other. If the variance of the residual one observation to another observation remains then it is called homoscedasticity. A good regression model is if there is no heteroscedasticity. From the

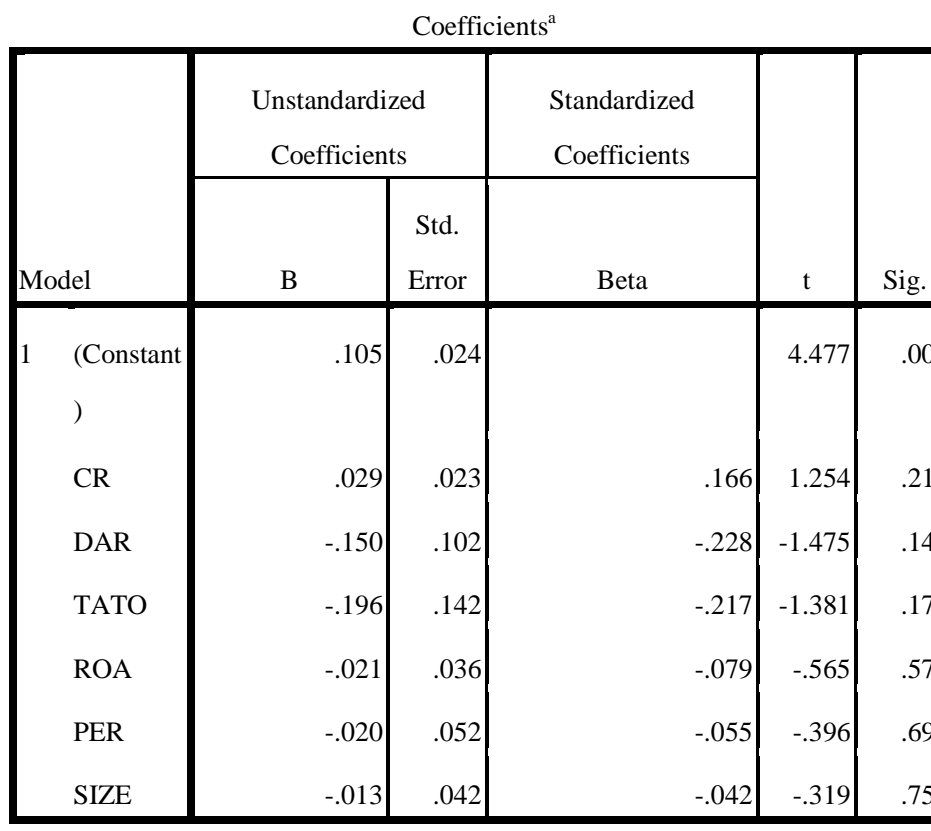

table 4.3 the value of variable significance of liquidity / Current Ratio 0,216, significance of solvability variable (DAR) 0.147, activity variable (TATO) 0,174, profitability variable (ROA) 0,575 and variable PER 0, 695. The significance value of the five independent variables is greater than $\alpha=0.05$ it means the regression model does not occur heteroscedasticity.

Table 4.3

\section{Heteroscedasticity Test}

Company size as a control variable value of significance 0.752 , greater than $\alpha=0.05$ it means that regression model did not occur heteroscedasticity.

\section{d. Multicolinearity Test}

The purpose of multicollinearity test is to find out whether the regression model found a correlation between independent variables (independent). A good model should not have a correlation between independent variables (no multicolonierity).

If the VIF value is less than 10, then there is no multicollinearity to the data being tested. Conversely, if the VIF value is greater than 10 , it means multicollinearity to the data being tested.

From the results of multicolinearity test in table 4.4 obtained VIF value CR 1.067 variable, DAR variable 1.449 , TATO variable 1,495, ROA variable 1,191 and variable PER 1,193. VIF value of Size variable as varabel kontro 1,034. VIF value of the five independent variables and one control variable is smaller than 10 so it can be said that the model there is no multicollinearity between these variables.

Table 4.4

Multicollinearity Test Results

Data source: secondary data processed, 2017

\begin{tabular}{c|c|c|c}
\hline Variabel & Tolerance & VIF & Infromation \\
\hline CR & 0,937 & 1,067 & Did not happen multikolinearitas \\
DAR & 0,690 & 1,449 & Did not happen multikolinearitas \\
TATO & 0,669 & 1,495 & Did not happen multikolinearitas \\
ROA & 0,840 & 1.191 & Did not happen multikolinearitas \\
PER & 0.838 & 1,193 & Did not happen multikolinearitas \\
SIZE & 0,967 & 1,034 & Did not happen multikolinearitas \\
\hline
\end{tabular}


From multicolinearity test results obtained values of tolerance values CR 0.937 variables, DAR variable 0.690 , TATO variable 0.669 , ROA variable 0.840 and PER 0.838 variables. The tolerance value of the Size variable as the control variable is 0.967. The tolerance value of the five independent variables and one control variable is greater than 0.1 so it can be said that the model does not have multicollinearity among variables.

\subsubsection{Hypothesis testing}

\section{a. Multiple Linear Regression Equation}

Table 4.5

Summary of Hypothesis Test Results

\begin{tabular}{|c|c|c|c|c|}
\hline Variable & b & $\mathbf{T}_{\text {count }}$ & Sig & Conclusion \\
\hline Konstans & 0,137 & & & \\
\hline $\mathrm{CR}$ & 0,043 & 1,278 & 0,207 & No Significant \\
\hline DAR & $-0,206$ & $-1,414$ & 0,164 & Impact \\
\hline TATO & $-0,739$ & $-3,642$ & 0,001 & No Significant \\
\hline ROA & 0,974 & 18,745 & 0,000 & Impact \\
\hline PER & $-0,079$ & $-1,075$ & 0,288 & Significant \\
\hline SIZE & $-0,013$ & $-0,216$ & 0,830 & Influence \\
\hline & & & & $\begin{array}{l}\text { Significant } \\
\text { Influence }\end{array}$ \\
\hline & & & & No Significant \\
\hline & & & & Impact \\
\hline & & & & No Significant \\
\hline & & & & Impact \\
\hline \multicolumn{2}{|l|}{$\mathrm{F}_{\text {count }}$} & 68,322 & 0,000 & $\begin{array}{l}\text { Significant } \\
\text { Influence }\end{array}$ \\
\hline \multicolumn{2}{|l|}{$\mathrm{R}^{2}$} & \multicolumn{3}{|c|}{0,882} \\
\hline
\end{tabular}

Based on the calculation of SPSS that appear in table 4.5 regression equation as follows:

$\mathrm{Y}=0,137+0,043 \mathrm{CR}-0,206 \mathrm{DAR}-0,739$

TATO + 0,974 ROA - 0,079 PER - 0,013

$\mathrm{SIZE}+\mathrm{e}$

From the analysis results, it can be seen that the independent variables that have a positive effect on profit growth is Current Ratio with coefficient of 0.043 and Return On Assets with coefficient 0.974. This means that when the Current Ratio, and Return on Total Assets increases then profit growth also increases. While the independent variables that negatively affect the profit growth is Debt Assets Ratio with coefficient 0.206, Total Assets Turn Over with coefficient 0.739 and Price Earning Ratio with coefficient 0.974 . This means that if the Debt Assets Ratio, Total Assets Turn Over and Price Earning Ratio decreased the profit growth increased and vice versa.

Company size as control variable is negatively affect profit growth with coefficient 0,013 .

\section{b. Individual Parameter Significant Test (-} t Statistic Test)

The $\mathrm{t}$ test is used to know the partial significance of the independent variables: Curent Ratio $\left(\mathrm{X}_{1}\right)$, Debt Assets Ratio $\left(\mathrm{X}_{2}\right)$, Total Assets Turn Over $\left(\mathrm{X}_{3}\right)$, Return On Assets $\left(\mathrm{X}_{4}\right)$ and Price Earning Ratio $\left(\mathrm{X}_{5}\right)$ namely: Profit Growth $(\Delta \mathrm{Y})$.

From table 4.5 above is known magnitude influence of each independent variable to the dependent variable is as follows:

a) Test the hypothesis of the influence of Current Ratio on profit growth.

From the calculation results $t$ significance for the variable Ratio of $0.207>\alpha(0,05)$. This means that the Current Ratio in partial has no significant effect on profit growth with the size of the company as a control variable.

b) Test the hypothesis Debt Assets Ratio to profit growth.

From the calculation results obtained significance $\mathrm{t}$ for the variable Debt Assets Ratio of $0.164>\alpha(0.05)$. This means that Debt Assets Ratio has no significant effect to profit growth with firm size as control variable.

c) Hypothesis test Total Assets Turn Over on profit growth

From the calculation results obtained $t$ significance for the variable Total Assets Turn Over Ratio of $0.001<\alpha(0.05)$. This means Total Assets Turn Over has a significant effect on profit growth with firm size as a control variable. 
d) Test the hypothesis Return On Assets to profit growth

From the calculation results obtained significance $\mathrm{t}$ for the variable Return On Assets of $0.000<\alpha(0.05)$. This means Return On Assets has significant effect to profit growth with firm size as control variable.

e) Test the hypothesis Price Earning Ratio to profit growth

From the calculation results obtained significance $\mathrm{t}$ for Price Earning Ratio variable of $0.288>\alpha(0.05)$. This means Price Earning Ratio has no significant effect to profit growth with firm size as control variable.

c. F Test

From the results of statistical calculations using SPSS shown in table 4.5 obtained $\mathrm{F}$ value count of 68.322 with a significance level of 0.000 . The resulting significance value of $F$ is smaller than $\alpha=0.05$. This means that the variable Current Ratio, Debt Assets Ratio, Total Assets Turn Over, Return On Assets, Price Earning Ratio and Size control variables simultaneously significantly influence the profit growth variable.

d. Coefficient of Determination $\left(\mathrm{R}^{2}\right)$

From the calculation results with SPSS program that appears in table 4.5 can be seen that the coefficient of determination that can be seen from Adjusted R Square, obtained for 0.882 . This means that $88.2 \%$ of profit growth can be explained by the variable Current Ratio, Debt Assets Ratio, Total Assets Turn Over, Return On Assets, Price Earning Ratio and Size in this study, while the remaining $11.8 \%$ is explained by other variables that are not investigated in this study.

\subsection{Discussion}

Individual test result using $t$ test shows that there are only two variables, namely growth of Total Assets Turn Over and growth of Return on Assets which have significant effect to profit growth of companies incorporated in LQ 45 Index 2013-2016.
The results of this study indicate the growth of Total Assets Turn Over significantly affect the profit growth of companies incorporated in the LQ 45 Index 2013-2016. It can be assumed the asset turnover of the company in generating profits is very effective, where Total Assets Turnover has a positive influence on Profit Growth. The faster the level of asset turnover then the net profit generated will increase because the company can take advantage of assets to increase sales that affect the income. Thus the more effective asset turnover of the company or the management of assets capable of producing high performance companies that can increase corporate profits and impact on increasing the return rate (return) in the investor can. The results of this study are in line with the results of Ade Gunawan and Sri Fitri Wahyuni which states there is significant influence of Total Assets Turnover on Profit Growth at Trading companies listed in Indonesia Stock Exchange period 2006-20 2011. The results of this study in line with the results of I Nyoman Kusuma Adnyana Mahaputra stated that there is a significant influence of Total Assets Turnover on Profit Growth at manufacturing companies listed on BEI. The results of this study are in line with the results of Nita Hari Susanti's research which states Total Assets Turnover partially significant effect on future earnings growth in automotive companies in Indonesia Stock Exchange.

Likewise, according to the theory of Van Horne and Wachowicz (2005, p.221) states that Total Assets Turnover describes the relationship of net sales with total assets. Total Asset Turnover indicates the capability of funds embedded in the overall rotating asset in a given period or the capability of the capital invested to generate a "Revenue".

The results of this study are not in line with research conducted by $\mathrm{R}$. Adisetiawan which states Total Assets Turnover has no 
significant effect on profit growth in trading companies in Indonesia Stock Exchange.

The results of this study indicate the growth of Return on Assets significantly influence the profit growth of companies incorporated in the LQ 45 Index 2013-2016.

The results of this study can be assumed that every one dollar assets invested in companies incorporated in the LQ45 Index effectively generate profits. Positive Return On Assets (ROA) show that the total assets used for the company's operations are able to provide profits for the company. Conversely, if the negative ROA shows the total assets used do not give a profit.

The results of this study in line with research conducted Nita Hari Susanti which states Return on Assets partially significant effect on profit growth in automotive companies in Indonesia Stock Exchange.

The individual test result using $t$ test is found that the variable that influence is not significant to the profit growth of companies incorporated in Index LQ 45 is variable growth Curent Ratio, growth Debt Asset Ratio and growth Price Earning Ratio.

The results of this study stated that the Curent Ratio has no significant effect on profit growth in companies incorporated in the LQ45 Index. This means that the company's ability to meet its short-term liabilities does not guarantee the availability of working capital to support the company's operational activities, so that the profit to be achieved is not as expected. This means investments in current assets are too great that could be due to the company trying to maintain a high level of liquidity. Liquidity levels that are too high will have an adverse effect on profit growth because current assets generally result in lower returns than fixed assets.

The result of this research is in line with research of Ade Gunawan and Sri Fitri Wahyuni which stated that Current Ratio has no significant effect on Profit Growth in Trading company registered in Indonesia Stock Exchange period 2006-2011.
The results of this study are not in line with the research I Nyoman Kusuma Adnyana Mahaputra which shows that the current ratio has a significant influence on profit growth.

The results of this study indicate that the growth of Debt Asset Ratio has an insignificant effect on profit growth in companies incorporated in the LQ45 Index. This indicates that investment in the wealth of companies incorporated in the LQ45 Index is more financed from external sources of financing / from debt. The source of financing from outside the company / from the debt impacts the increase of interest expense to be paid by the company, so this gives an impact on the decrease of company's profit. This could mean the inability of the Debt To Assets Ratio to influence profit growth is possible because the result of investments in the wealth of companies funded from the debt fund is not able to cover the entire interest expense to be paid by the company resulting in a decrease in profits earned even the company could lose.

The results of this study are in line with the research of Ade Gunawan and Sri Fitri Wahyunu (2013) but contrary to the results of research Dra. Isnaniah Laili Khatmi Safitri, MMA (2016) which states Debt to Asset Ratio has a significant influence on profit growth of PT. Kalbe Farma tbk.

The results of this study states that the growth of Price Earning Ratio has an insignificant effect on profit growth in companies incorporated in the LQ45 Index. This can be assumed even though the PER of LQ45 Index is increased but it is not followed by the increasing of investor confidence in the future of the company so that it does not trigger the increase of share price of companies incorporated in LQ 45 Index.

\section{Conclusions and Suggestion}

\subsection{Conclution}


The conclusions of this study are as follows: 1. The changes in Current Ratio have no significant effect on profit growth with firm size as control variable. This means that the company's ability to meet its short-term liabilities does not guarantee the availability of working capital to support the company's operational activities, so that the profit to be achieved is not as expected.

2. The changes in Debt Assets Ratio have no significant effect on profit growth with firm size as control variable. This indicates that investment in the wealth of companies incorporated in the LQ45 Index is more financed from external sources of financing / from debt. The source of financing from outside the company / from the debt impacts the increase of interest expense to be paid by the company, so this gives an impact on the decrease of company's profit.

3. The changes in Total Assets Turn Over have a significant effect on profit growth with firm size as control variables. It can be assumed that asset management of companies incorporated in the LQ45 Index in generating profits is very effective, in which Total Assets Turnover has a positive effect on profit growth. The faster the turnover rate of the net income generated will increase because the company can already utilize assets to increase sales that affect the income.

4. The change On Assets have significant effect to profit growth with company size as control variable. The results of this study can be assumed that every one dollar assets invested in companies incorporated in the LQ45 Index effectively generate profits. Positive Return On Assets (ROA) show that the total assets used for the company's operations are able to provide profits for the company.

5. The changes in Price Earning Ratio have no significant effect on profit growth with firm size as control variable. This can be assumed even though the PER of LQ45 Index is increased but it is not followed by the increasing of investor confidence in the future of the company so that it does not trigger the increase of share price of companies incorporated in LQ 45 Index.

6. The changes in Current Ratio, Debt Assets Ratio, Total Assets Turn Over, Return On Assets, Price Earning Ratio and Size control variables simultaneously have a significant effect on profit growth.

\subsection{Suggestion}

a. If the companies incorporated in the LQ45 Index want to have an increased profit growth to support the company's performance, it is advisable that the company increase the effectiveness of the asset management so that the total asset turnover increases because if the investment in the assets of the company is too much then the capital cost is too high and the profit will be depressed. On the other hand, if the assets are too low, the profitable sales will be lost.

b. Suggested companies in investing wealth using a funding source that can to improve the profit growth of the company. The use of debt can be justified to the extent that it is expected to provide an additional operating profit greater than the interest paid.

c. Given the results of this study are still many variables that are not significant, should researchers further use the other financial ratios that have a strong predictive power of profit growth.

\section{Refferences}

Ade Gunawan dan Sri Fitri Wahyunu. Management and Bussines Journal. Vol. 13 No. 01 April 2013. ISSN. 1693-7619

Agus Sartono, 2001. Finance Management Theory and Practice. Yogyakarta: BPEF-Yogyakarta.

Anto Dajan.2000. Introduction to Statistical Methods. Volume I. II. LP3ES. Jakarta

Bambang Riyanto. Company Spending Basics. Fourth edition. Yogyakarta. Yayasan Penerbit Gajah Mada. 1995. 
Ghozali, Imam. 2005. Application of Multivariate Analysis with SPSS. Semarang: Badan Penerbit UNDIP

Handono Mardiyanto, 2008, Digest of Financial Management: Jakarta

I Nyoman Kusuma Adnyana Mahaputra. Journal of Accounting \& Business. Vol. 7, No. 2, July 2012

Isnaniah Laili Khatmi Safitri, MMA. Journal of Accounting and Business. Volume 2 Number 2.Nopember 2016

Juliana, Roma Uly dan Sulardi. Benefits of Financial Ratios In Predicting Changes in Profit of Manufacturing Companies. Journal of Business \& Management, Vol. 3, No.2.2003

Nita Hari Susanti (2014) Journal of Management Science \& Research Vol. 3 No. 5 (2014)

Prihadi, Toto. 2008. Quick Detection of Financial Condition: 7 Financial Ratio Analysis. PPM, Jakarta.

R. Adisetiawan. Journal of Application Management. Volume 10. Number 3. September 2012
Sartono, Agus. 2001. Financial Management Theory and Applications. The fourth edition, BPFE, Yogyakarta.

